\title{
Sampling for vegetative propagation: A phytosanitary status survey of grapevines collection by One Step RT-PCR method
}

\author{
M. Yzeiraj \\ Agricultural Technology Transfer Center Vlorë, Shamogjin, Vlorë Municipality, Albania, e-mail: melaize.yzeiraj@gmail.com
}

Purpose. Grapevines (Vitis spp.) are affected by many viral diseases which cause serious pathological problems. GLRaV-3 is among the most widespread leafroll viruses, while Grapevine Fanleaf Virus (GFLV) is a destructive pathogen which reduces the lifespan of grapevine. Considering the impact and the spread of these diseases, our objective was to analyse the presence of these two viruses in several grapevine varieties in grapevine collection at ATTC Vlore. Data gathered from plant pathogens serve to better understand and prevent the spread of pathogens, as a mandatory rule for the quality control of certified plant material during vegetative propagation. Method. The presence of two common viruses were tested using virus specific primers; LC1/LC2 primer pair designed from the hHSP70 gene for detecting Grapevine Leafroll-associated Virus-3 (GLRaV3) and C3390/H2999 primer pair, designed from coat protein coding regions for detecting Grapevine Fanleaf Virus (GFLV), in six varieties; 'Merlot', 'Kallmet', 'Shesh i zi', 'Shesh i bardhë', ‘Debinë', and 'Pulëz', provided through a randomised sampling procedure. One Step Reverse Transcription Polymerase Chain Reaction assay was used to detect the viral presence. Results showed a high (100\%) prevalence of GLRaV3 virus in all of analysed samples, as the most frequent among the two pathogens. Analysis for of GFLV virus showed low infection rate, being present in only one sample. Conclusions. We herein show an efficient, fast and reproducible method for detecting grapevine viruses through one step RT-PCR. Our results suggest that sampling of the infected plant material should be avoided due to the presence of viral infections.

Keywords: one step RT-PCR; RNA extraction; grapevine varieties; GLRaV3; GFLV; vegetative propagation.

\section{Introduction}

Grapevine (Vitis spp.) is one of the most important economic species in the world [4] at the same time showing the highest number of intracellular infections. Among the potential listed threats are bacteria, fungi, oomycete and viruses with distinct characteristics, infection mechanisms and evasion strategies [1]. To date, there are more than 60 viral species reported to infect grapevines [13]. The main viruses infecting grapevines are closteroviridis which are associated with leafroll disease; flexiviridis related to rugose wood disease complex; and nepoviruses, which are responsible for fanleaf degeneration, as a major economic threat.

The production of propagative material has a beneficial impact on the health conditions of the viticultural industry. It implements stra-

Melaize Yzeiraj

https://orcid.org/0000-0002-7492-624X tegies such as sanitary improvements of the crops and certification of nursery products for assuring quality standards [13]. In the very specific case of grapevine certification, it involves detection of viral infections, clonal identification and viticultural performance. As certified virus-free vineyards are more productive and have reported fewer problems, efforts are made to provide high standards to harmonize grapevine certification protocols, in order to ensure that no viticultural region is compromised by the introduction and spread of diseases [6].

In this study we have analysed the presence of Grapevine leafroll associated virus-3 (GLRaV-3), a phloem limited virus, being widespread and producing significant economic losses around the world [16] and Grapevine fanleaf virus (GFLV), one of the most-studied Xiphiniema nematode transmitted virus due to its negative economic impact on grapevine, causing fanleaf degeneration as one of the most severe and destructive viral disease of grapevine, reducing fruit quality and longevity of vineyards $[5,21]$. Considering the de- 
structive potential and economic loss these viruses cause, the main aim of the research was to establish a reliable and efficient protocol for detecting viruses in grapevines through RT-PCR. This technique is recommended by EPPO (European and Mediterranean Plant Protection Organization) as an appropriate method for certification, mainly due to detection of several plant viral infections, including leafroll (GLRaV's) and especially Fanleaf (GFLV) virus, being rapid, sensitive, reliable, reducing the contamination risk and circumventing the problem with low viral concentration, compared to serological techniques $[3,13,19,24]$.

RT-PCR has gained a lot of popularity for detection and diagnosis of plant viruses. As one of the most frequently used diagnostic technique, it is well established, validated and standardized. In addition, RT-PCR is known for its high sensitivity, ease of implementation and relatively low cost $[18,23]$. However, other advanced techniques are currently in use for plant diagnostics such as: array technologies (which allow simultaneous detection of multiple plant viruses), quantitative PCR, and NGS (next generation sequencing) a revolutionary technique used to discover and characterize novel viruses and viral strains [23].

Reliable, early and correct detection methods are the most effective actions to develop control strategies for plant viral diseases management [18] however the future challenge might be to design strategies for preventing a quick sanitary deterioration of vineyards [13]. The aim of this study is to help in estimating the feasibility of grapevine sampling for vegetative propagation. This is relevant in context of mandatory rules for the use of certified plant material for vegetative reproduction, as an effective way to prevent the spread of pathogens.

\section{Material and methods}

\section{Plant material and RNA isolation}

Samples were taken randomly from mature leaves, petioles and phloem tissue of six varieties: 'Merlot', 'Kallmet', 'Shesh i zi', 'Shesh i bardhë', 'Debinë', 'Pulëz'. Pestles, mortars, and all glassware were kept for 4 hours at $200{ }^{\circ} \mathrm{C}$ [9] and plasticware autoclaved before use [4]. Samples were homogenized using mortar and pestle in liquid nitrogen. Two extraction protocols were followed; CTAB-TRIzol ${ }^{\circledR}$ and CTAB-LiCl. The first was a modified CTAB-TRIzol ${ }^{\circledR}$ combination method, where the first step is treatment with CTAB solution [9] followed by TRIzol ${ }^{\circledR}$ extraction protocol, according to the manufacturer's protocol (TRIzol ${ }^{\circledR}$ Reagent, Invitrogen) [8]. According- ly, about $100 \mathrm{mg}$ of pulverized plant material was treated for ten minutes at $56{ }^{\circ} \mathrm{C}$ in $900 \mu \mathrm{l}$ CTAB solution ( $2 \%$ CTAB, $100 \mathrm{mM}$ tris $\mathrm{HCl}$, $20 \mathrm{mM}$ NaEDTA, $1.4 \mathrm{M} \mathrm{NaCl}, 2 \%$ PVP) where $1 \% \beta$-mercapthoethanol was added prior to use. The samples were centrifuged and the suspension was treated with $900 \mu \mathrm{l}$ TRIzol and incubated at $4{ }^{\circ} \mathrm{C}$ overnight. The following procedures were based on manufacturer guidelines and consist of; adding twice $0,2 \mathrm{ml}$ chloroform, incubation for 5 minutes and centrifugation for $15 \mathrm{~min}$. Isopropanol was added to the aqueous phase, incubated for $10 \mathrm{~min}$, the pellet was washed with $75 \%$ ethanol, centrifuged, air dried, and resuspended in $50 \mu \mathrm{l}$ RNase free water.

The second method is CTAB- LiCl protocol according to Ling et al. [11]. During the first step, samples were treated with $1 \mathrm{ml}$ of $3 \%$ CTAB solution and incubated at $65{ }^{\circ} \mathrm{C}$ for 30 minutes with occasional shaking. The supernatant was collected and centrifuged for $15 \mathrm{~min}$ at room temperature. An equal volume of chloroform-isoamyl alcohol $(24: 1, \mathrm{v} / \mathrm{v})$ was added and centrifuged. The supernatant was collected and $1 / 3$ volume of $10 \mathrm{M} \mathrm{LiCl}$ was added and overnight incubated at $4{ }^{\circ} \mathrm{C}$. The other extraction steps were performed as previously reported [11]. The spectrophotometric absorbance was evaluated at 230,260 , and $280 \mathrm{~nm}$, using a UV-3100PC (VWR) spectrophotometer. The integrity of extracted RNA was evaluated on $1 \%$ agarose gel. The data were analysed using JMP 16 Statistical Software.

\section{RT-PCR Analysis}

Reverse transcription reactions were carried out with SuperScript IV One Step RT-PCR system (Invitrogen) with LC1/LC2 primers designed from the hHSP70 gene for GLRaV3 virus [15] and H2999/C3310 primers for GFLV virus, designed from coat protein coding regions [12]. The amplification was performed in a total volume of $25 \mu \mathrm{l}$, containing: $12,5 \mu \mathrm{l} 2 \mathrm{X}$ Platinum $^{\text {TM }}$ SuperFi $^{\text {TM }}$ RT-PCR Master Mix, $10 \mu \mathrm{M}$ specific forward and reverse primer, $0.5 \mu$ l SuperScript ${ }^{\mathrm{TM}}$ IV RT Mix, a maximum of $0.5 \mu \mathrm{g}$ RNA template and nuclease free water up to $25 \mu \mathrm{l}$. The PCR reactions were carried out on a thermal cycler 2720 (Applied Biosystems) using the following program; 30 minutes reverse transcription at $52{ }^{\circ} \mathrm{C}$, denaturation at $94{ }^{\circ} \mathrm{C}$ for $5 \mathrm{~min}, 35$ cycles at $94{ }^{\circ} \mathrm{C}$ for $30 \mathrm{sec}$, annealing at $52{ }^{\circ} \mathrm{C}$ for $30 \mathrm{sec}$ (GLRaV3) and $60{ }^{\circ} \mathrm{C}(\mathrm{GFLV}), 72{ }^{\circ} \mathrm{C}$ for $50 \mathrm{sec}$ and a final extension at $72{ }^{\circ} \mathrm{C}$ for $7 \mathrm{~min}$ as described by Osman and Rowhani [17], Turturo et al. [21] (Table 1). Each of the experiment was repeated at 
least three times to assure the reproducibility of the assay. The amplified products were resolved by electrophoresis on $1.5 \%$ agarose gel buf- fered in TBE (45 mM Tris-borate, $1 \mathrm{mM}$ EDTA) and visualised using UV light after staining with GelRed (Biotium).

Sequences of specific primers for detecting GLRaV3 and GFLV in grapevines

\begin{tabular}{|c|c|c|c|}
\hline Virus & Primer sequence & Amplified DNA size & Reference \\
\hline GLRaV3 & $\begin{array}{l}\text { LC1 5' CGCTAGGGCTGTGGAAGTATT 3' } \\
\text { LC2 5' GTTGTCCCGGGTACCAGATAT 3' }\end{array}$ & 546 bp & [15] \\
\hline GFLV & $\begin{array}{l}\text { H2999 5' TCGGGTGAGACTGCGCAACTTCCTA 3' } \\
\text { C3310 5' GATGGTAACGCTCCCGCTGCTCTT 3' }\end{array}$ & 312 bp & [12] \\
\hline
\end{tabular}

\section{Results and discussion}

The nucleic acid isolation method is a critical factor for success, influenced by multiple parameters, including the efficiency of isolating extracts containing enough RNA and free of inhibitors. However, RNA isolation procedure can be challenging due to the presence of phenolic compounds and polysaccharides in woody plants tissues, including grapevines. These factors could substantially inhibit PCR reactions components $[10,17]$. Phenolic compounds bind to proteins and nucleic acids forming high molecular weight complexes, meanwhile polysaccharides tend to co-precipitate with RNA, remaining as contaminants in the final extract.

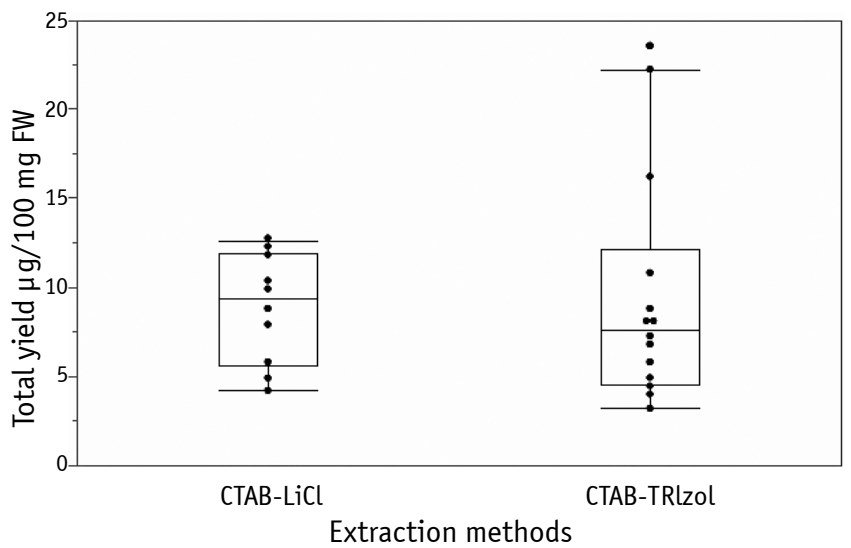

a

Figure 1. Boxplot chart comparing (a) CTAB-LiCl and CTAB-TRIzol ${ }^{\oplus}$ total yield/100 $\mathrm{mg}$ FW and (b) RNA purity $A_{260} / A_{280}$ ratio for both extraction methods. Charts were built using statistical software JMP 16
Among the two methods used, RNA-TRIzol ${ }^{\circledR}$ extraction resulted in higher RNA yield of $9.55 \pm 1.74 \mu \mathrm{g} / \mathrm{mg}$, while CTAB-LiCl method recorded a total yield of $8.83 \pm 0.96 \mu \mathrm{g} / \mathrm{mg}$ (Fig. 1a). On the other hand, CTAB-LiCl resulted in higher purity ratio $2.049 \pm 0.07$, while CTAB-TRIzol ${ }^{\circledR}$ recorded an average ratio of $1.85 \pm 0.13$ (Fig. 1b). High molarity $\mathrm{LiCl}$ solution precipitate RNA from DNA and favours larger transcripts precipitation, however $\mathrm{CTAB}+\mathrm{LiCl}$ is a time consuming method
Comparative results of the two methods used for isolation of the RNA showed that the methods we have used were efficient and reproducible for RT-PCR analysis. Choosing the appropriate extraction method is essential for detecting grapevine viruses through molecular diagnostic techniques and one must consider the simplicity and reproducibility of it [13].

The results of this study point out that RNA extraction procedures performed are suitable for routine use in diagnostic laboratories. CTABTRIzol ${ }^{\circledR}$ procedure is relatively rapid and produces a high total RNA yield, meanwhile using CTAB-LiCl resulted as an effective procedure to obtain high purity RNA, free from phenolic and polysaccharides compounds (Fig. 1).

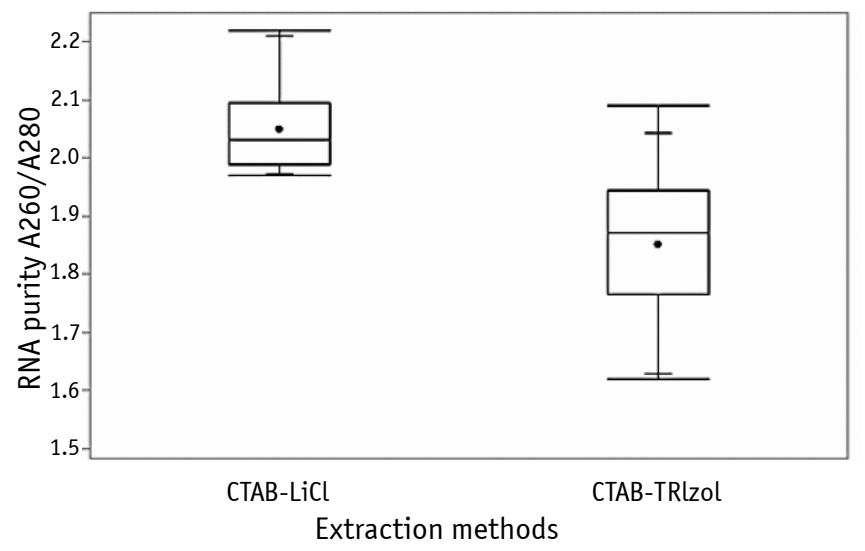$$
\text { b }
$$

[4]. RNA purity, defined by A260/280 ratio, is a measure of proportion between RNA and protein [2] and showed that CTAB-LiCl method provided a value of around 2 for the RNA purity, which make it a suitable method for RNA extraction.

The average incidence of infection for each tested virus was $100 \%$ for GLRaV3 and $2.8 \%$ for GFLV for the cultivars under study (Table 2). Our findings are similar to previous reports, like that of Hančević et al., [7] who 
have detected the presence of GLRAV3 virus in around $95 \%$ of the studied samples. These results indicate that GLRaV3 virus is more frequent in terms of distribution compared to GFLV, as previously reported by serological assays performed [20]. Merkuri et al., [14] reported that GFLV was the least represented virus in native varieties with an infection rate of $5.5 \%$, observed in 5 out of 16 cultivars tested. Meanwhile leafroll disease is present in native and foreign cultivars, exceeding an incidence of $60 \%$ in certain varieties.

Analysed cultivars and overall infection

Table 2 (number of samples infected/total number of samples tested)

\begin{tabular}{|l|c|c|c|c|c|c|c|}
\hline \multicolumn{1}{|c|}{ Cultivar } & 'Merlot' & 'Shesh i zi' & 'Shesh i Bardhë' & 'Kallmet' & 'Debinë' & 'Pulëz' & Overall infection \\
\hline GLRaV3 virus & $6 / 6$ & $6 / 6$ & $6 / 6$ & $6 / 6$ & $6 / 6$ & $6 / 6$ & $100 \%$ \\
GFLV virus & $0 / 6$ & $0 / 6$ & $0 / 6$ & $0 / 6$ & $1 / 6$ & $0 / 6$ & $2.8 \%$ \\
\hline
\end{tabular}

The phytosanitary conditions of Albanian viticulture do not have any significant difference compared to the neighbouring and Mediterranean countries. These conditions require ade- quate measures to improve the sanitary quality of the crop through selection and sanitation programmes, similarly with those administered in several countries of Mediterranean region [14].
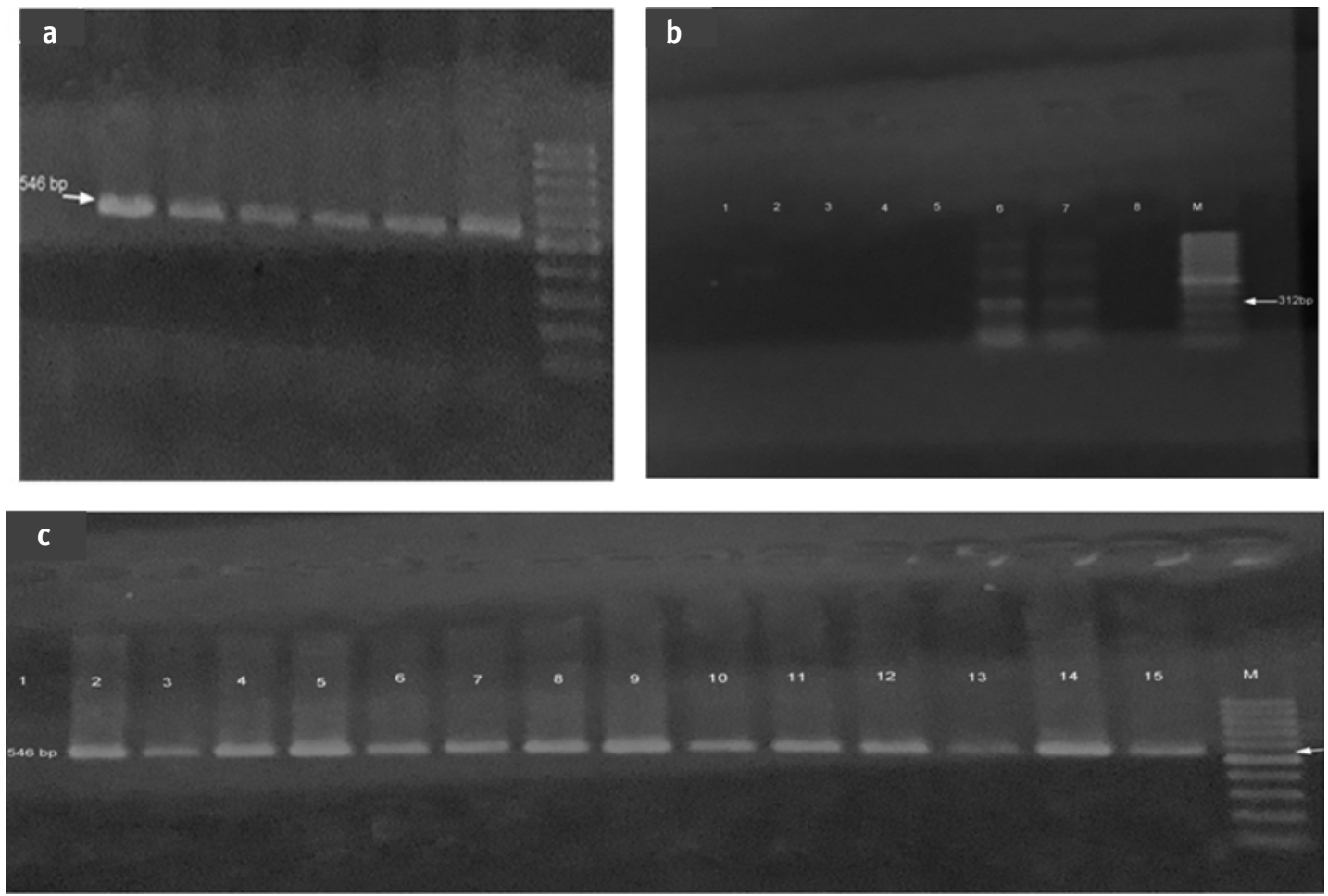

Figure 2. Gel electrophoresis images of tested samples in $1.5 \%$ agarose gel.

(a) All samples of 'Merlot' variety tested for GLRaV3, (b) M - 100 bp, 1 - 'Kallmet', 2 - 'Pulës', 3 - 'Shesh i zi', 4 - 'Shesh i Bardhë', 5 - 'Merlot', 6 - 'Debinë', 7 - Positive Control, 8 - Negative Control, (c) M - 100 bp, 1 - Negative control, 2 - Positive control, 'Pulës' (3, 4), 'Debinë' $(5,6)$, 'Kallmet' (7, 8, 9), 'Shesh i bardhë' $(10,11,12)$, and 'Shesh i Zi' $(13,14,15)$ tested for GLRaV3

Expected fragment length with LC1/LC2 primer pair is 546 bp [15], as it's shown in the figure $2 \mathrm{a}$ and $2 \mathrm{c}$, where amplified fragments consist of $546 \mathrm{bp}$ and can be observed in all of the studied samples. The analysis for the presence of GFLV virus tested by H2999/C3310 primer pair, resulted in an expected amplified fragment size of $312 \mathrm{bp}$ [12] as it's shown in the Figure $2 b$, recorded from one of the 'Debinë' variety samples.

\section{Conclusions}

In this study we have analysed the presence of viral diseases through an effective, reliable and reproducible assay. Considering the high frequency of infected vineyards by GLRaV3 and the relatively lower presence but considerable threat of GFLV, we conclude that sampling of plant material from analysed grapevines plantation is accompanied with the risk 
of viral transmission diseases, thus this practice is not suggested to be used. With a focus on certification, it's essential to adapt an action plan with measures against harmful pathogens. It's suggested to replace infected grapevine plants, as a measure to maintain the disease under control. Prevention of viral diseases spread across vineyards can prevent plant deterioration, increase product quality and provide sanitation at the same time.

\section{References}

1. Armijo, G., Schlechter, R., Agurto, M., Muñoz, D., Nuñez, C., \& Arce-Johnson, P. (2016). Grapevine Pathogenic Microorganisms: Understanding Infection Strategies and Host Response Scenarios. Front. Plant Sci., 7, 382. doi:10.3389/fpls.2016.00382

2. Chaparro-Encinas, L. A., Arellano-Wattenbarger, G. L., ParraCota, F. I., \& de los Santos-Villalobos, S. (2020). A modified CTAB and Trizo ${ }^{\circledR}$ protocol for high-quality RNA extraction from whole wheat seedlings, including rhizosphere. Cereal Res. Commun., 48(3), 275-282. doi: 10.1007/s42976-020-00046-9

3. Pathogen-tested material of grapevine varieties and rootstocks. (2008). EPPO Bulletin, 38(3), 422-429. doi: 10.1111/ j.1365-2338.2008.01258.x

4. Gambino, G., Perrone, I., \& Gribaudo, I. (2008). A rapid and effective method for RNA extraction from different tissues of grapevine and other woody plants. Phytochem. Anal., 19(6), 520-525. doi: 10.1002/pca.1078

5. Garcia, S., Hily, J., Komar, V., Gertz, C., Demangeat, G., Lemaire, 0., \& Vigne, E. (2019). Detection of Multiple Variants of Grapevine Fanleaf Virus in Single Xiphinema index Nematodes. Viruses, 11(12), 1139. doi:10.3390/v11121139

6. Golino, D. A., Fuchs, M., Al Rwahnih, M., Farrar, K., Schmidt, A., \& Martelli, G. P. (2017). Regulatory Aspects of Grape Viruses and Virus Diseases: Certification, Quarantine, and Harmonization. In B. Meng, G. Martelli, D. Golino, \& M. Fuchs (Eds.), Grapevine Viruses: Molecular Biology, Diagnostics and Management (pp. 581-598). Springer Int. Publ. doi: 10.1007/978-3-319-57706-7_28

7. Hančević, K., Saldarelli, P., Čarija, M., Černi, S., Zdunić, G., Mucalo, A., \& Radić, T. (2021). Predominance and Diversity of GLRaV-3 in Native Vines of Mediterranean Croatia. Plants, 10(1), 17. doi: 10.3390/plants 10010017

8. Invitrogen, TRIzol reagent. Retrieved from http://tools.thermofisher.com/content/sfs/manuals/trizol_reagent.pdf

9. Jordon-Thaden, I. E., Chanderbali, A. S., Gitzendanner, M. A., \& Soltis, D. E. (2015). Modified CTAB and TRIzol protocols improve RNA extraction from chemically complex Embryophyta. Appl. Plant Sci., 3(5), 1400105. doi: 10.3732/apps.1400105

10. Lacroix, C., Renner, K., Cole, E., Seabloom, E. W., Borer, E. T., \& Malmstrom, C. M. (2016). Methodological Guidelines for Accurate Detection of Viruses in Wild Plant Species. Appl. Environ. Microbiol., 82(6), 1966-1975. doi: 10.1128/AEM.03538-15

11. Ling, Z., Zhike, Z., Shunquan, L., Tingting, Z., \& Xianghui, Y. (2013). Evaluation of Six Methods for Extraction of Total RNA from Loquat. Not. Bot. Horti Agrobot. Cluj Napoca, 41(1), 313316. doi: $10.15835 /$ nbha4118233

12. MacKenzie, D. J., McLean, M. A., Mukerij, S., \& Green, M. (1997). Improved RNA extraction from woody plants for the detection of viral pathogens by reverse transcriptase-polymerase chain reaction. Plant Disease, 81(2), 222-226. doi: 10.1094/ PDIS.1997.81.2.222

13. Maliogka, V. I., Martelli, G. P., Fuchs, M., \& Katis, N. I. (2015). Control of Viruses Infecting Grapevine. In Advances in Virus Research (pp. 175-227). Elsevier. doi: 10.1016/bs.aivir.2014.11.002

14. Merkuri, J., Martelli, G. P., Boscia, D., \& Savino, V. (1994). Viruses of grapevine in Albania. EPPO Bulletin, 24(1), 215-220. doi: 10.1111/j.1365-2338.1994.tb01062.x

15. Minafra, A., \& Hadidi, A. (1994). Sensitive detection of grapevine virus A, B, or leafroll-associated III from viruliferous mealybugs and infected tissue by cDNA amplification. J. Virol. Methods, 47(1-2), 175-187. doi: 10.1016/01660934(94)90076-0

16. Montero, R., El aou ouad, H., Flexas, J., \& Bota, J. (2016). Effects of grapevine leafroll associated virus 3 (GLRaV-3) on plant carbon balance in Vitis vinifera L. cv. Giró Ros. Theor. Exp. Plant Physiol., 28(1), 1-10. doi: 10.1007/s40626-015-0050-6

17. Osman, F., \& Rowhani, A. (2006) Application of a spotting sample preparation technique for the detection of pathogens in woody plants by RT-PCR and real-time PCR (TaqMan). J. Virol. Methods, 133(2), 130-136. doi: 10.1016/j.jviromet. 2005.11.005

18. Pallás, V, Sánchez-Navarro, J. A., \& James, D. (2018). Recent Advances on the Multiplex Molecular Detection of Plant Viruses and Viroids. Front. Microbiol., 9, 2087. doi: 10.3389/ fmicb.2018.02087

19. Ragozzino, E., Faggioli, F., \& Barba, M. (2004). Development of a one tube-one step RT-PCR protocol for the detection of seven viroids in four genera: Apscaviroid, Hostuviroid, Pelamoviroid and Pospiviroid. J. Virol. Methods, 121(1), 25-29. doi: 10.1016/j.jviromet.2004.05.012

20. Sadikaj, D., Cara, M., \& Merkuri, J. (2016). Phytosanitary Status of Some Albanian Grapevine Varieties with Reference to main Viral Diseases. Albanian J. Agric. Sci., Special Ed., 49-52.

21. Turturo, C., Saldarelli, P., Yafeng, D., Digiaro, M., Minafra, A., Savino, V., \& Martelli, G. P. (2005). Genetic variability and population structure of Grapevine leafroll-associated virus 3 isolates. J. Gen. Virol., 86(1), 217-224. doi: 10.1099/vir.0.80395-0

22. Ulea, E., Irimia, N., \& Lipşa, F. D. (2012). Serological detection of Grapevine fanleaf virus (GFLV) in ampelographic collection from USAMV Iaşi (Romania). Res. J. Agric. Sci., 44(2), 108-111.

23. Yadav, N., \& Khurana, S. M. P. (2016). Plant Virus Detection and Diagnosis: Progress and Challenges. In Frontier Discoveries and Innovations in Interdisciplinary Microbiology (pp. 97-132). Springer India. doi: 10.1007/978-81-322-2610-9 7

24. Youssef, S. A., Moawed, S. M., El-Sayed, M., \& Shalaby, A. A. (2010). Detection of olive tree viruses in Egypt by one-step RT-PCR. Julius-Kühn-Archiv, 427: 21st International Conference on Virus and other Graft Transmissible Diseases of Fruit Crops, 51-52. Retrieved from https://ojs.openagrar.de/index. php/JKA/article/view

Yzeiraj М. Обстеження фітосанітарного статусу колекції винограду методом одностадійної ЗТ-ПЛР. Plant Varieties Studying and Protection. 2021. T. 17, № 2. C. 164-169. https://doi.org/10.21498/25181017.17.2.2021.236525

Agricultural Technology Transfer Center Vlorë, Shamogjin, Vlorë Municipality, Albania, e-mail: melaize.yzeiraj@gmail.com

Мета. Рослини винограду (Vitis spp.) уражуються багатьма вірусними збудниками, що спричиняють їхні серйозні захворювання. До найпоширеніших належать вірус скручування листя винограду (GLRaV-3) та вірус коротковузля винограду (GFLV), деструктивний патоген, який зменшує тривалість життя виноградної лози. 3 огляду на важливість і поширення захворювань, що спричиняються згаданими вірусами, нашою метою було проаналізувати їхю присутність у сортах винограду з колекції Центру Трансферу Агарних Технологій (ATTC Vlore). Отримані дані про рослин- 
ні патогени потрібні для запобігання їхньому поширенню i $€$ обов'язковими для контролювання якості сертифікованого рослинного матеріалу під час його вегетативного розмноження. Методи. Наявність вірусів перевіряли методом одностадійної 3Т-ПЛР з використанням вірус-специфічних праймерів: пара праймерів LC1 / LC2, що розроблена для детектування гена hHSP70 вірусу скручування листя винограду-3 (GLRaV3), і пара праймерів С3390 / H2999, для визначення кодувальних послідовностей білка оболонки вірусу коротковузля винограду (GFLV). Аналіз шести сортів культури - 'Merlot', 'Kallmet', 'Shesh i zi', 'Shesh i bardhë',
‘Debinë' i ‘Pulëz' - здійснювали з використанням процедури рандомізованої вибірки. Результати. Найпоширенішим вірусом для досліджених зразків виявився GLRaV3, який траплявся у $100 \%$ проаналізованих рослин. Визначення вірусу GFLV показало низький рівень інфікування, вірус був лише в одному зразку. Висновки. Показана можливість використання одностадійної ЗТ-ПЛР як ефективного, швидкого й відтворюваного методу виявлення вірусів виноградної лози.

Ключові слова: одностадійна ЗТ-ПЛР; екстракція РНК; сорти винограду; GLRaV3; GFLV; вегетативне розмноження. 